\title{
DUTCH RELIGIOUS LOVE EMBLEMS: REFLECTIONS OF FAITH AND TOLERATION IN THE LATER 17TH CENTURY
}

\author{
Els Stronks
}

\begin{abstract}
In this article, I examine the process of appropriation demonstrated in early modern Dutch religious love emblems published in the Dutch Republic around I700. These religious love emblems were adaptations of Roman Catholic emblem books, originally made by Jesuits or priests in the Southern Netherlands around I630. The reconstruction of the network formed by these religious emblems in the Republic, and an analysis of the gaps between the originals and their adaptations, allow us to take a closer look at changing attitudes towards religious faith and religious toleration at the time.
\end{abstract}

\section{INTRODUCTION}

The history of religious toleration in Western Europe has recently become the focus of interest amongst historians. Many of them believe that the present-day efforts to achieve a social equilibrium among competing faiths might benefit from the historical lessons to be drawn from the struggle between Roman Catholics and Protestants in the early modern era. An important contribution to this area of research was recently offered by Benjamin F. Kaplan. His study Divided by Faith: Religious Conflict and the Practice of Toleration in Early Modern Europe ${ }^{1}$ focusses on regions in Europe with the most complex religious maps, such as Switzerland, the Low Countries and the German principalities. Kaplan argues that laypeople played a significant role in managing and containing confessional conflicts in these regions in the early modern era. Laypeople established forms of 'peaceful coexistence'2 long before the concept of religious toleration was discussed amongst intellectuals during the Enlightenment.

Although Kaplan pays tribute to the achievements of research carried out in the field of literary studies, stating that this discipline devised new Literature \& Theology (C) The Author 2009. Published by Oxford University Press 2009; all rights reserved. For Permissions, please email: journals.permissions@oxfordjournals.org 
methodologies and approaches to history by shedding light on the opinions and mentalities of laypeople, ${ }^{3}$ he does not make extensive use of (popular) religious literature as a resource for the reconstruction of lay attitude towards religious toleration. He only mentions some (polemic) pamphlets and gives the names of a few authors who found an audience amongst all religious denominations. ${ }^{4}$ Supplementing Kaplan's thesis, I will argue that shifts in religious toleration can be traced by studying constructional processes in early modern religious literature. The focus of this article is on Dutch literature and, in particular, on a number of late I 7 th century religious love emblem books made by Protestant emblematists. The present article is a first, cautious foray, as just a few characteristic examples from one literary genre are highlighted. Supplementary research in the coming years will hopefully shed more light on the relation between interconfessional literary exchange and the practice of religious toleration. ${ }^{5}$

\section{THE TRANSMISSION OF ROMAN CATHOLIC CULTURE TO}

THE DUTCH REPUBLIC

The late I7th century Protestant religious love emblems found their origin in Roman Catholic emblem books made around I630 in the Southern Netherlands by Jesuits or priests. As was recently mentioned by Aakanksha Virkar-Yates in her article on the emblematic sources of Gerard Manley Hopkins's The Wreck of the Deutschland (I876), ${ }^{6}$ the most influential of these Flemish Roman Catholic emblem books was the Pia Desideria (I624) by Hermannus Hugo, which became popular in England amongst Protestant readers in almost unchanged form: ${ }^{7}$

The Anglican metaphysical poet Francis Quarles is well known for his Emblems (I635), [a] reworking of Hugo's text that altered little of its original Jesuit source and yet came to be the best-known emblem book in English history $[\ldots]^{8}$

In contrast, the reception of Hugo's Pia Desideria and related Roman Catholic religious love emblem books amongst Protestants in the Dutch Republic was quite different. ${ }^{9}$ Amongst Roman Catholics, the Pia Desideria was received with great enthusiasm; but the publication, in I653, of the first Protestant adaptation of the Pia Desideria by the mystic and Chiliast Petrus Serrarius, titled Goddelycke aandachten [Divine meditations], went by almost unnoticed. ${ }^{10}$ It took over thirty years before the Pia Desideria was again introduced into Protestant circles, this time by Jan Luyken in his Jezus en de Ziel [Jezus and the Soul], published in I678. 


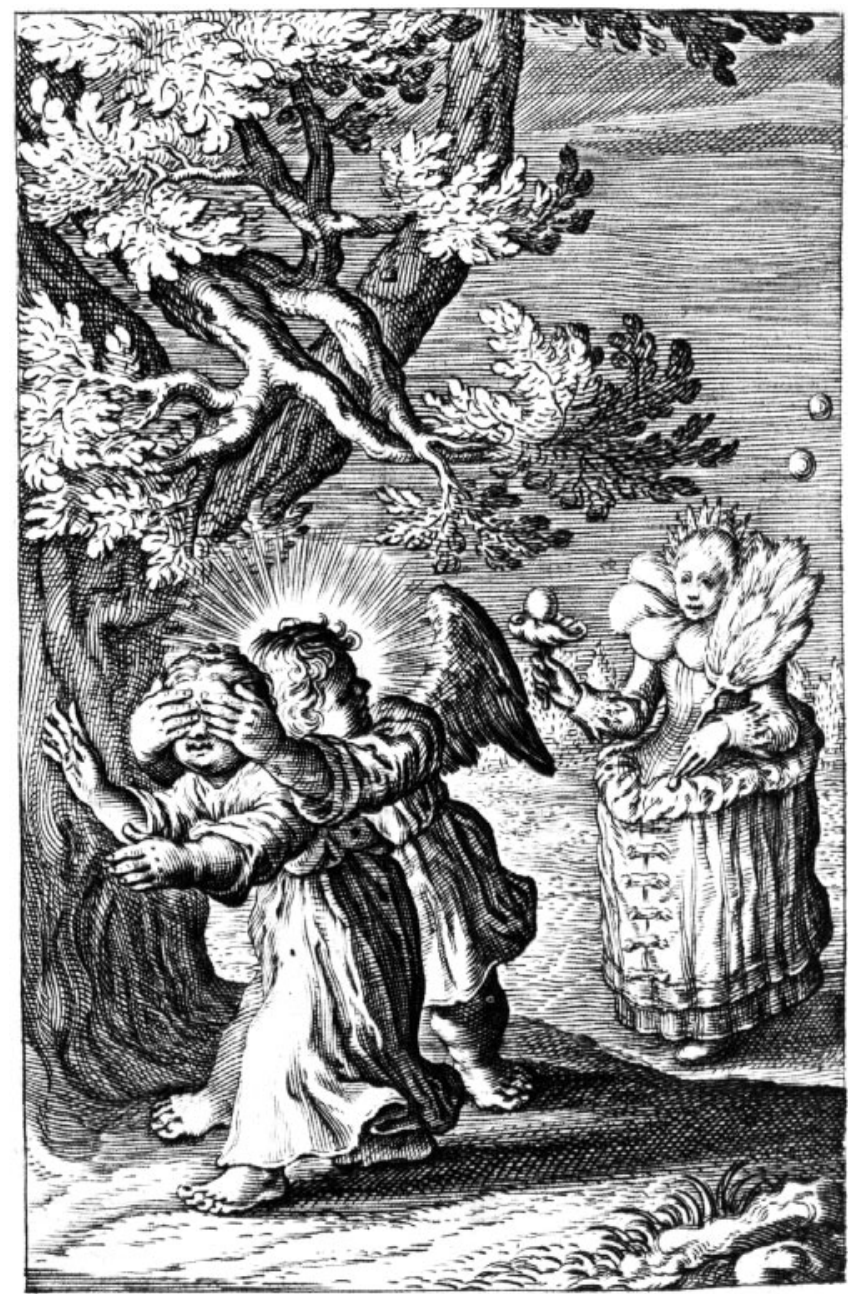

Auerte oculos meos ne videant vanitatem. Pfal. ne.

FIG. I. Hugo (I624), Pia Desideria, emblem 20.

On this occasion Hugo's original emblems were transformed rather than translated by Luyken. Three picturae taken from Hugo's, Quarles's and Luyken's emblem books may serve to illustrate this point. ${ }^{11}$

I will return to the differences between these picturae and the accompanying texts (mottoes and subscriptios) below. First, however, let us focus our attention on the depicted figures. All three picturae show configurations of three personae: the believer's soul (portrayed as a young girl), divine love (portrayed as a haloed angel), and the world (portrayed as a woman-prosperously dressed in the case of Hugo and Charles). With Hugo and Quarles, 


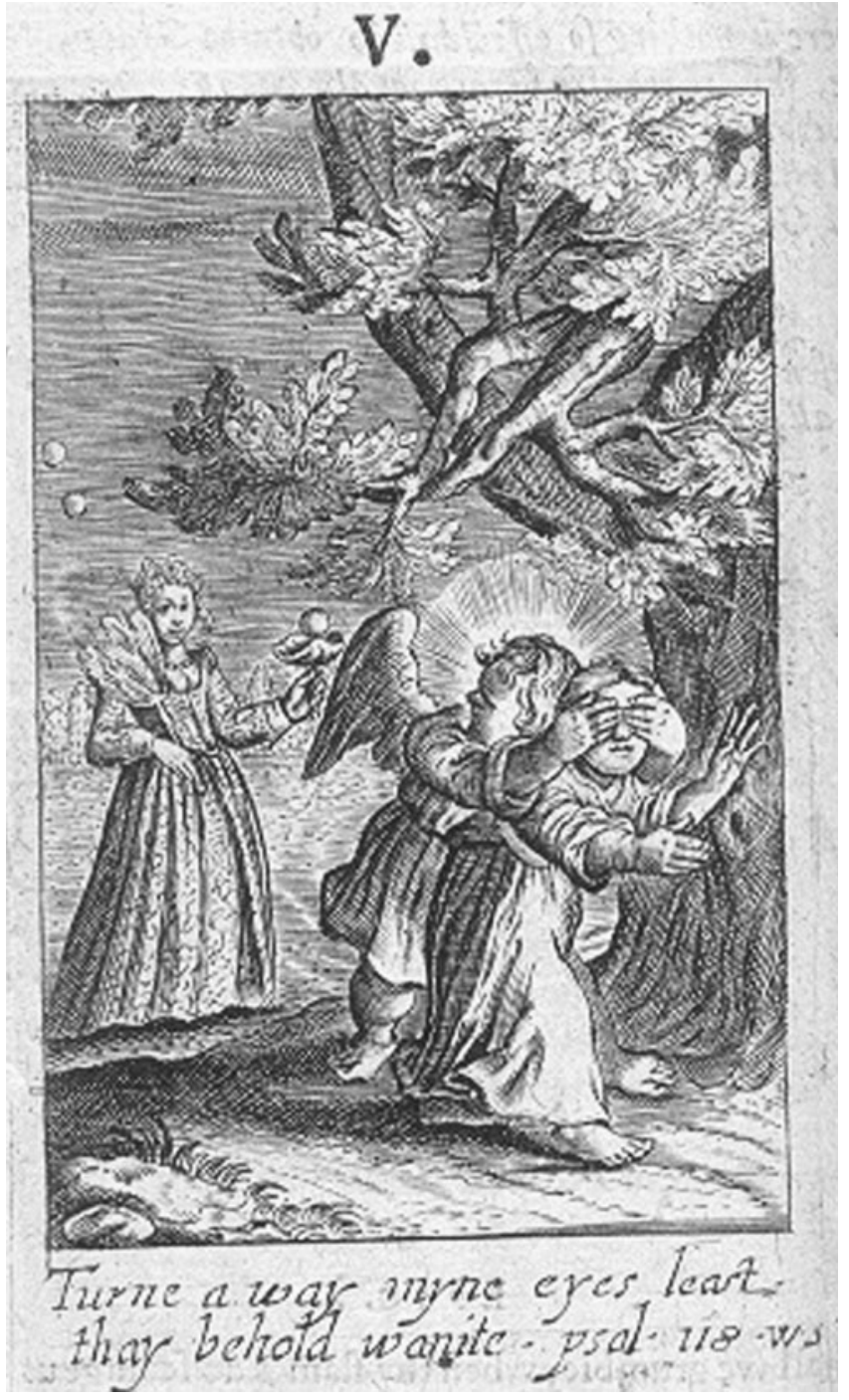

FIG. 2. Quarles (I635), Emblems, Divine and Moral, book 4, emblem V.

the latter figure symbolises the world's mutability by carrying a fan and blowing bubbles. The eyes of the believer's soul are covered by divine love's hands, in what looks like an almost redundant gesture, since the young girl is already being led away from the woman.

The same theme-the struggle of the soul with worldly temptations-is treated in a different manner by Luyken. In his pictura, the soul is talking to the world, who is no longer wearing a luxurious dress, but is still recognised as a wealthy persona because she is portrayed against a backdrop of a luxurious 


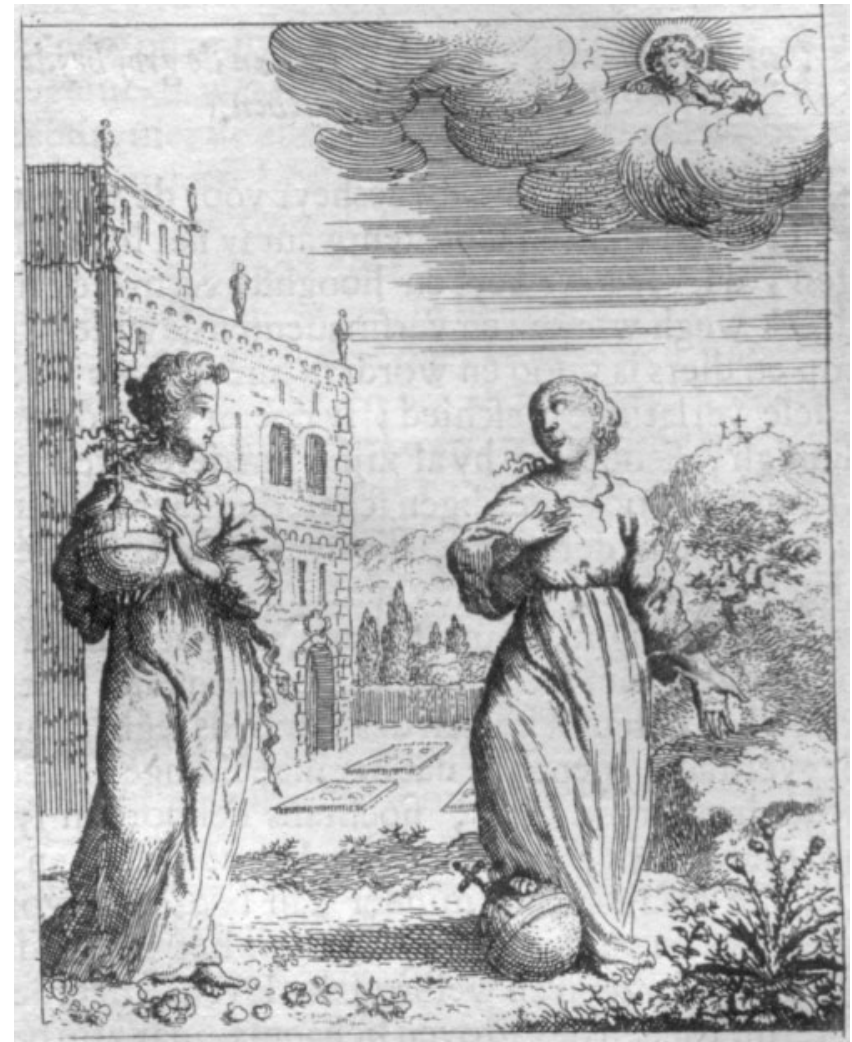

Fig. 3. Luyken (1678), Jezus en de Ziel, emblem 30.

house and carefully kept garden as if to emphasise her nature and origins in a more subtle way: the reader has to look beyond her first appearance to notice her true luxurious nature. The world is holding a globe, pointing at it as if she is trying to recommend it to the soul. The soul's eyes are wide open and are not directed towards the globe, but to the eyes of the world. She is, in turn, standing on a globe, as if to show her disapproval of the world and the luxury associated with it; the world no longer presents a threat to her; she is dominating it rather than being seduced by it. Divine love, who watches the two from above, appears to be quietly supporting the soul rather than acting as her guide and mentor. Although working with the same personae, Luyken attaches a different message to the scene. He portrays the soul as an independent young women, who is making her own choices, being watched rather than guided by divine love. Even though Luyken's world is not easily recognised for what she is, the soul is able to look right through her and is eventually in control of the situation. 
Luyken's example of transforming the Roman Catholic religious love emblems was soon followed by other Protestant emblematists. Their work rapidly became widely popular: there was a succession of numerous reprints in a short period of time and printers aimed at making the emblems available to a large public by publishing affordable editions or reprints of the picturae that were to be sold separately. ${ }^{12}$ How is the large-scale reception of such works from a Roman Catholic legacy into the Dutch Republic to be interpreted in light of the practice of religious toleration amongst laypeople during the period I678-I720? The timing of the revival of Roman Catholic religious love emblems in the Republic is remarkable, since many scholars have argued that, during the last quarter of the I 7 th century, Roman Catholic doctrine, and, in particular, its Jesuit exponent, was severely disputed in the Dutch Republic. For example, 'the growth of anti-Catholicism in the Netherlands' after I680, as a reaction to the cruelties committed by Roman Catholics towards the Huguenots elsewhere in Europe, and the coronation of the Roman Catholic James II in England in I685, was recently mentioned by John Marshall in his study John Locke, Toleration and Early Enlightenment Culture. ${ }^{13}$ Maarten Prak has shown that this growing antipathy led to the enforcement of anti-Catholic legislation in the eastern and southern parts of the Dutch Republic during the last quarter of the 17 th century. ${ }^{14}$ According to Jonathan Israel, this was a sign of the times: between I670 and I720 the Dutch Republic lost the open debate culture that had been typical for the Republic between I600 and I650, when the Dutch were allowed to overtly express deviating opinions on religious issues. ${ }^{15}$ This all changed, according to Israel, when the Dutch began to rigorously contest Spinoza's as well as Descartes' philosophy and ideas during the years I670-I720.

As Kaplan suggests, it has been common practice, until recently, to base these changes in the social climate on certain contemporary discussions amongst the elite, probably because at the time it was the elite's opinionsarticulated by philosophers, theologians and politicians - that were voiced most clearly and published in books and pamphlets attracting widespread attention, not only in the early modern era, but also in the centuries to come. At the same time, there is some alternative evidence suggesting that on a day to day basis, the inhabitants of the Dutch Republic were increasingly crossing confessional borders during the course of the I 7 th century. Interconfessional relationships and friendships between Protestants and Roman Catholics, for instance, came to be more openly accepted, according to recent studies into in the Dutch Republic. ${ }^{16}$

The case of the religious love emblems appears to indicate that around I685 new opportunities arose for the appropriation of Roman Catholic culture. This article presents an estimation of the scope and significance of adaptations made by Protestant emblematists, serving as an indication of 
developments in the practice of religious toleration. This approach is based on a theoretical framework designed by Roger Chartier, who-as so many others-assumes that literature does not provide an 'immediate, transparent, unmediated access' to the past. Literary sources are determined and shaped by 'a particular relation to the reality they designate: depiction, representation, prohibition, prescription, quantification, and so on. ${ }^{17}$ If one wishes to reconstruct a given text's historical reading as well as the historical mentalities it reflects, one can analyse the process of appropriation borne out in new texts that are based upon previous texts and read by a new public. In this approach, the 'old' and the 'new' text are considered as form variants of a single (postulated) text. The gaps between old and new texts act as signposts for the new readers' construction of meaning. In other words, the similarities and differences point towards certain shifts in emphasis, in the new texts, which steer the public in the direction of a certain interpretation. ${ }^{18}$ In examining the process of appropriation which Protestant poets manifest, I expect to be able to make a number of claims about the context of these poems.

Almost all of the Protestant emblematists were Anabaptists, and I am also taking this denomination into account, although it is not presupposed that a similar denomination in the poets' audience is necessarily implied. Especially in Luyken's case, it has been established that his work was popular with a broad range of diversely oriented Protestant readers; his picturae had a life entirely of their own and adorned the walls of a great many Dutch living rooms. ${ }^{19}$ In other genres too it has often been noted that in the Dutch Republic religious literature-especially hymns - easily surpassed the dividing lines of religious denominations. ${ }^{20}$

\section{THE EMBLEM AS A REFLECTION OF EARLY MODERN SOCIETY}

Using emblems to reconstruct aspects of early modern mentality is a workable method because the emblematic genre was intertwined with society from its very incipience in I53I, when the first emblem book was created by the Italian lawyer Andrea Alciati. The numerous emblems books in Europe which were modelled after Alciati's example shared a tendency towards the moralistic and were meant to supply answers to questions concerning moral conduct, such as how to behave as a husband, a scholar, a friend, an old man, etc. ${ }^{21}$ In I 567, the Protestant Georgette de Montenay published her Cent Emblemes Chrestiens in Paris. This emblem book gave the existing tradition of the profane emblem a religious counterpart. From that moment on, religion and confessional strategies became a constitutive part of the love emblematic tradition. ${ }^{22}$ 
The subgenre of 'love emblematics' that came to be created in the Dutch Republic around I600 was especially known for its practical qualities-just as other Dutch emblems they represented events and objects from everyday life, thus playing an important role in establishing and forming cultural identities in Dutch society. ${ }^{23}$ The profane love emblems in particular were instrumentalised as new and modern forms of instruction, proffering guidelines on communication between the sexes, especially regarding marriage.

The ties between Dutch society and the love emblem became even more significant after the first decade of the I7th century. ${ }^{24}$ The first love emblem books-Daniel Heinsius's Emblemata Amatoria, Otto Vaenius's Amorum Emblemata and Pieter Cornelisz. Hooft's Emblemata Amatoria-were composed along the lines of the rather unrealistic, Petrarchan concept of love, but a more practical approach was introduced after I6IO. As an illustration of this development, it is noteworthy to point out that when the policy for national trade was debated amongst politicians in the Republic, love emblems began to reflect this debate on a semantic level. ${ }^{25}$ The following emblem, taken from Heinsius's Ambacht van Cupido [Trade of Cupid] shows how the productivity of wedlock is praised and propagated in the economical terms of profit, opportunities and investments:

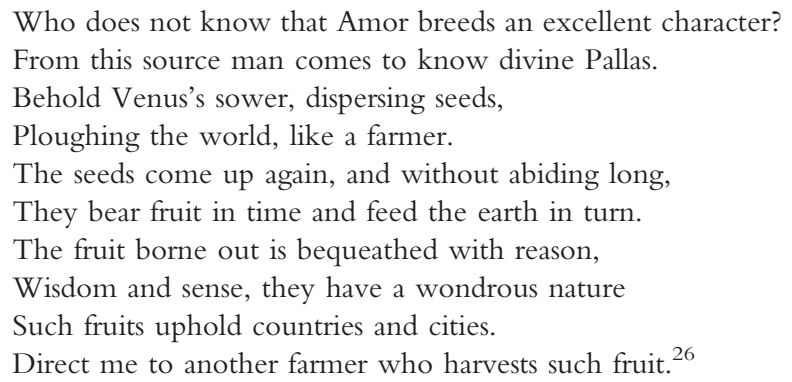

The motto refers to the classical myth of Pallas (born out of love, from the head of her father) and the biblical parable of the sower. Together with the pictura, positioned below the motto, the phrase 'Amazing Seeds of Love' forms a riddle which is not easily solved by the reader. However, the author helps to solve the riddle bit by bit in the subscriptio. The reader's attention is first focussed on the classical myth in the first two lines. A rhetorical question, to which an answer is given in the next line, reveals the meaning of the heads which seem to be growing out of the fields. This is a standard dialectical situation in early modern education. The communication between teacher and pupil normally followed the pattern of questions and answers, both in classroom reality and in printed textbooks. The rest of the subscriptio then focusses on the biblical parable of the sower (spilling some of his seeds, but 


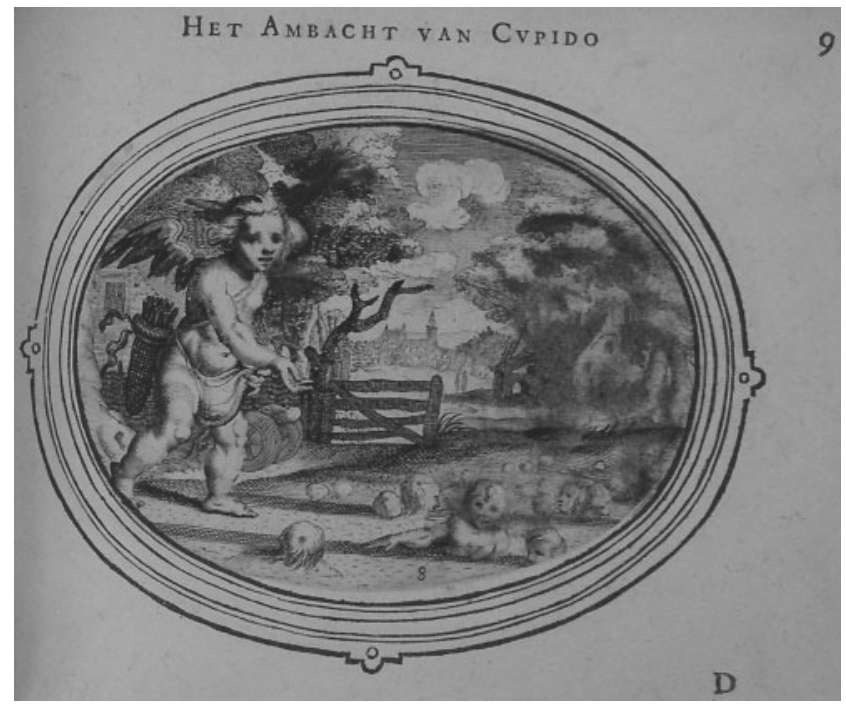

Fig. 4. Heinsius (I613), Ambacht van Cupido, emblem 8.

making good use of the rest), combining the reference to Pallas's wisdom with the wise nature of the sower. The early modern reader was familiar with the allegorical as well as moralistic nature of the emblematic genre; and (young) Dutch readers were trained in finding the hidden moral lesson of images and texts. In this case, the science of love is taught: one should be prudent and wise in organising one's sexual desires along socially accepted lines, making the right investment and choices at the right time.

In the Dutch Republic, these kind of love emblems were used, at the beginning of the I7th century, to steer and organise a social change. Emblems taught youngsters the meaning of falling in love and the various stages in the development of an emotional relationship. Such instructions were needed because of socio-economic developments at the time: "Now that wealth was on the rise, young men went away from home for longer periods, studying at universities or traveling south on a Grand Tour. No longer in their parents' immediate surroundings, meeting new and often exciting people, how were they to control their emotions if they were hit by Cupid's arrow? ${ }^{27}$ The love emblems supported the individual in organising his/her emotions along socially accepted lines, making sure, for instance, that a wrong choice did not endanger the prosperity of whole families.

\section{THE RELIGIOUS LOVE EMBLEM}

Although these profane love emblems were never completely devoid of the sacred-as is evident from the use of the biblical metaphor of the sower 
in Heinsius's emblem and by the church depicted in the background-the love emblematics took a profoundly religious turn in I6I5 when Vaenius replaced Cupid, in his Amoris Divini Emblemata, with an angelic, childlike figure complete with wings and halo.

Vaenius's emblems bear the traces of both humanistic and Roman Catholic ideas. $^{28}$ The first wave of religious love emblems almost exclusively affected the Southern Netherlands. In the Dutch Republic only Jacob Cats's Sinneen Minnebeelden [Images of Meaning and Love] (I6I8/I627) can be placed within this tradition, although Cats's love emblems were given a moralistic rather than a religious turn. This is illustrated by the scant traces of Vaenius's Amoris Divini Emblemata in his Sinne- en Minnebeelden.

After I620, there was a gradual rise of religious love emblem books modelled on Vaenius's example. An important innovative stimulus to the genre was given by Hugo's engraver Boëtius à Bolswert, who transformed the pictura from a carrier of meaning into an expression of emotion, thus supporting Hugo in his meditative purposes. ${ }^{29}$ Around I630 the somewhat elite nature of religious love emblems, which were (partly) written in Latin, acquired a more accessible variant in the work of the priest Adriaan Poirters, who devoted himself to writing religious love emblems in Flemish for a nonintellectual public. $^{30}$

V. PROTESTANT APPROPRIATION OF THE RELIGIOUS LOVE EMBLEM: RHETORICAL CHANGES AND THE INTRODUCTION OF REALISM

In the Dutch Republic, it was Luyken who implemented the intellectual religious love emblem in the vernacular context. Although firmly fixed in the intellectual tradition of love emblematics, Luyken chose his own means when he adapted Jezus en de Ziel (I678) for a non-intellectual, Dutch audience. At this point, I would like to return to Hugo's emblem 'Averte oculos meos me vide' and Luyken's transformation of it in Jezus en de Ziel, in order to show how Luyken sought to establish an interactive relation with his readers, and stimulate them to make some changes in their lifestyles. Hugo wrote his Pia Desideria (I624) first of all for his fellow Jesuits. Acting more like a fellow believer than a teacher, he typically refrained from addressing the reader in the subscriptio accompanying the pictura, in which divine love covers the eyes of the soul. Written in the first-person singular, the text is intensely concentrated on the 'self - all the more so because the lyrical 'I' actually addresses her own eyes and thus chooses herself as a dialogue partner, showing the reader self-interrogation in action through interior dialogue: ${ }^{31}$ 
God, cover the roving eyes with shadows black as pitch,

Or lock my wandering eyes behind captive eyelids! ${ }^{32}$

The penitential mode in which this is all composed, with a sinner addressing God in prayer, full of self-accusation, is powerfully exploited by Hugo in the Pia Desideria, and was already very common in medieval religious lyric. ${ }^{33}$ The soul seeks to be unified with God, in the Pia Desideria, but such a union is constantly thwarted by the soul's penitential laments.

In Luyken's emblem, the motto 'De Ziele tegen de werelt' [The Soul against the world] indicates that the soul is actively fighting the world. The nature of this fight is detailed in the subscriptio, where the soul ('I') embarks on a dialogue with 'the world':

\footnotetext{
I am a fruit in the light, thou art in darkness

Each waxing from his soil until the time of ripeness is attained

Then each will joyfully harvest his fruit and store it in his barn

Your treasure will subside, mine will last forever.
}

Here, too, the identity of the lyrical voice is established through dialogue, but now it is in polemical opposition. At the end of the stanza, the soul concludes that the benefits of her life style are everlasting. The reader is persuaded to adopt a truly spiritual lifestyle by a poet who is actively searching to make contact with the reader. ${ }^{34}$

Luyken also changes Hugo's pictorial elements in order to establish a more direct and interactive relationship with the reader. The specific objects, landscape, and activities depicted in Luyken's Jezus en de Ziel must have been recognised as contemporary and Dutch at the time. Also, amor divinus and the soul are transformed by Luyken to ensure easier identification with these personae. Vaenius and Hugo had portrayed amor divinus and the soul as diminutive, childish figures, a type of representation that was indebted to the context of a spiritual environment already familiar with guardian angels and the Christchild. ${ }^{35}$ Luyken deviates from that pictorial tradition by choosing to represent amor divinus as an adult man, indeed as Jesus, as can be concluded from both the title Jezus en de Ziel, and the picturae. This point is further illustrated by comparing Luyken's title page and the pictura of the eighth emblem from the second part of Hugo's Pia Desideria. We can observe that Jesus and the soul make eye contact, while such contact is lacking in Hugo's pictura. ${ }^{36}$

By representing the marriage of the (human) figure and Jesus in a more realistic manner, Luyken again strengthens the relationship between the reader and his emblems.

A few years later, Jan Huygen took this kind of realism a step further in his Beginselen van Gods Koninkrijk [The Principles of the Kingdom of God], published in I689. The soul is now accompanied by a man who no longer 
ELS STRONKS

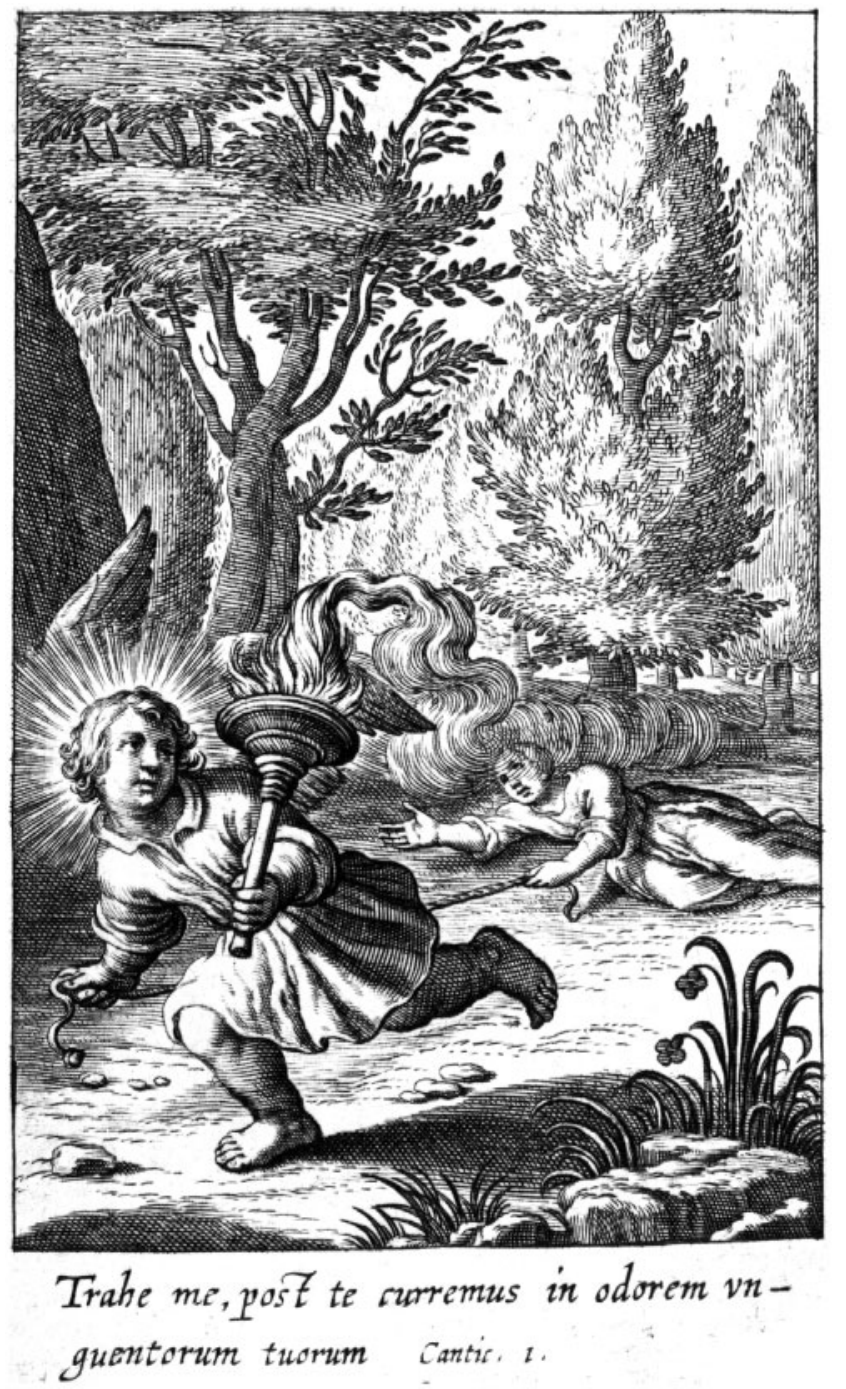

Fig. 5. Hugo (I624), Pia Desideria, emblem 23.

represents Jesus, but is just an older and wiser companion to the reader. Emblem number 8 from this emblem book displays the typical combination of realism (the Dutch interior), interactivity (the gestures and postures of the personae), and Roman Catholic elements (the enumeration of 'verstand, memorie, wil' [reason, memory, will]):

In the subscriptio the plural 'we' is used by the poet to urge the reader to act:

But, because it falls heavily on the degenerate mortal soul to accomplish these admonitions, 


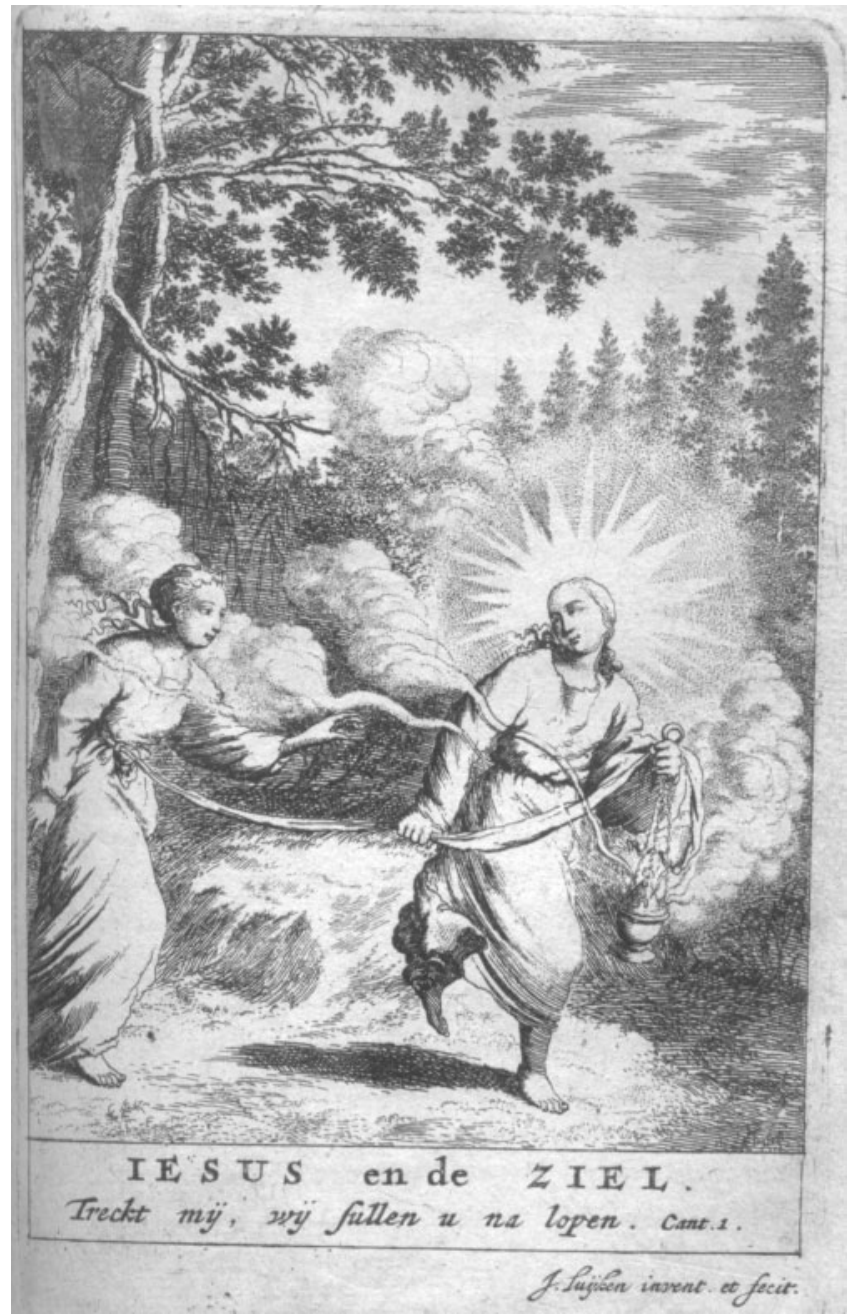

FIG. 6. Luyken (1678), Jezus en de Ziel, titlepage.

he needs to convert the commandments into prayer, And passionately, ceaselessly pray to the Lord [...] Oh! Then we will succeed in following God's ways As children adored, and perfect just as our Heavenly Father is perfect. ${ }^{37}$

In the attempt to minimalise the barrier between text and reader and ensure unhampered identification with the 'I' and 'we' of his emblems, Huygen explains the following in the preface to this book:

However, it is more important to me that you, reader, should know that if someone is presented who is talking, it should not be inferred that this represents 


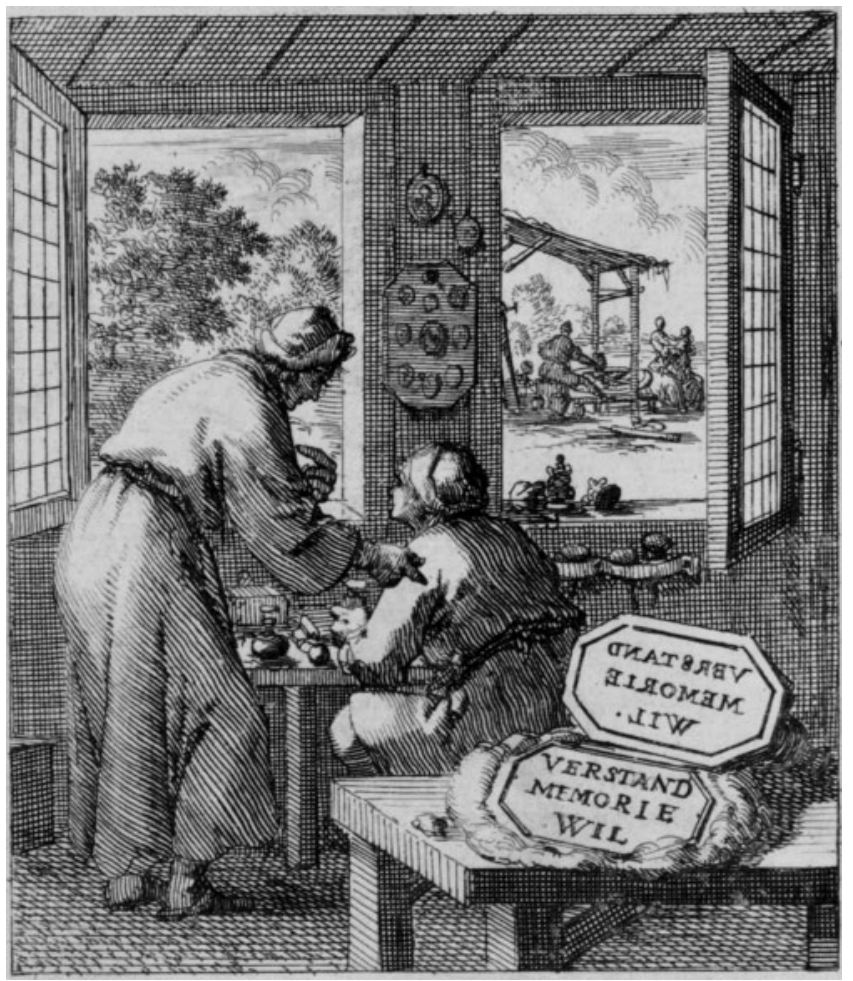

FIG. 7. Huygen (I689), Beginselen van Gods Koninkrijk, emblem 8.

my Person, but rather someone who might exist. [...] as someone who readily confesses that, to his shame, he has not yet attained that level. This is why I hope that this booklet will be like a mirror of teachings, both for my own soul and for yours. [...]. ${ }^{38}$

Luyken and Huygen focus on the praxis of piety, rather than on the unification with God. In their view, and that of many other Reformed pietists, ${ }^{39}$ this praxis is nurtured within the bond of parish or family. Departing from the idea of an individual, meditative journey towards God that prevailed with Hugo, the emblems of Luyken and Huygen seek to establish a rapport with the reader by giving the impression of the poet actively supporting the emotional journey towards a different lifestyle, and towards God.

VI. LIMITS TO THE APPROPRIATION OF ROMAN CATHOLIC SOURCES

Obviously, Luyken's Jezus en de Ziel and Huygen's Beginselen van Gods Koninkrijk demonstrate dependency on Roman Catholic emblem books, although both these authors created a (great) distance between their work 
$\mathrm{xx}$.

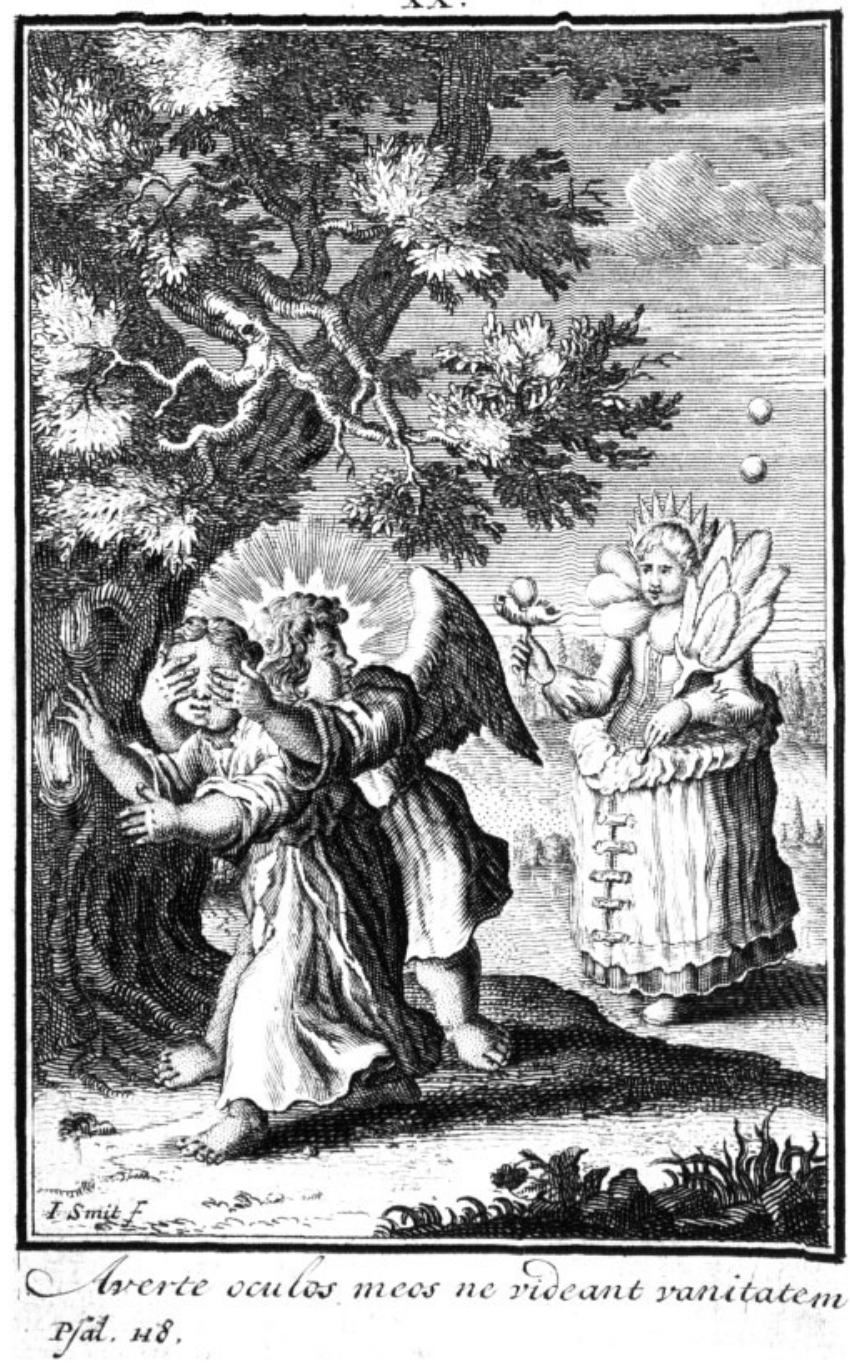

FIG. 8. Suderman (I724), De Godlievende Ziel, emblem 20.

and their sources. In some cases, however, Protestant emblematists appear to have stayed much closer to the origins of the genre. Judging for instance by Jan Suderman's De Godlievende Ziel [The God Loving Soul], published in I724, we can conclude that Protestant readers were sometimes confronted with almost exact copies of the original picturae, as is clear in the example of Suderman's 2oth picture, which is virtually identical to Hugo's pictura no. 20.

Yet, there were limits to what could be borrowed and what needed to be changed. Counteracting the impression that he might be encouraging physical 
worship of the (human) figure of Jesus - problematic in a Protestant contextLuyken added some explicit instructions to his preface in Jezus en de Ziel, with the intention to guide the reader towards the correct interpretation of the picturae in his emblems. ${ }^{40}$ And judging from his preface to De Godlievende Ziel, Suderman felt that by faithfully reproducing the original engravings and mottoes, he risked being perceived as an advocate of the 'unio mystica' which Hugo had presented as an ideal in Pia Desideria. He therefore wrote a lengthy explanation for his Protestant readership. First of all, he argues, 'the spiritual union of God and the soul' is a manner of speaking which is very common in the Bible, and therefore has a scriptural rather than a Roman Catholic origin:

And verily, the spiritual union of God and the soul, and of the soul and God is so completely internal that the $\mathrm{H}$. Bible knows of no other accurate description (if I may express myself thus) than to just say that they are one. [...] And rightly so, this is what caused the expressions of to lose one's self in God, to sink into God, to become one and united with God. Because, no matter the level of criticism against these expressions, or even the amount of mockery, I do not see that these, when considered in a spiritual context, as they should be, are any more concrete than the Word of our Lord Jesus Christ that we must eat his flesh, drink his blood for us to abide in Him and He in us. [...] It is undeniable then that the true Religion exists between God and our soul, which is something the world does not understand and therefore mocks. ${ }^{41}$

Second, there is in essence nothing wrong with the concepts of 'union' or 'mystical union' although these words are sometimes misconstrued:

I do not allege that there are no fanatics among those claiming themselves Mystics. Yet, I argue that one should differentiate between the Mystics who, by means of logical reasoning, express the union between the soul and God-albeit every now and then in too sophisticated phrasing-as compared to those who, by their own weakness of mind, do not walk in the ways of an inner belief.

The terms 'union' and 'mystic' could evoke the wrong associations, as Suderman says, since among the groups of believers who called themselves 'Mystics', both within the Roman Catholic church and among Suderman's own Protestant circles, ${ }^{42}$ there were (fanatic) people who claimed to experience the unification between their souls and God, but who were really only flaunting a weakness of mind, in their fanatic behaviour. True believers should realise that the union between God and the soul is only reached by silently studying His presence in ourselves: '[t]he soul needs to look within one's self to find God; only this would allow one to find one's self 
in God'. ${ }^{43}$ Logical reasoning with one's self, instead of losing one's self in irrational and weak behaviour, should lead to the kind of mystical unification Suderman had in mind; his emblems are presented as useful aids in this process.

\section{ViI. THE REligious DUtCH LOVE EMBlem in CONTEXT}

This small-scale investigation of the religious Dutch love emblem reveals that the interest in the Roman Catholic legacy which arose amongst Protestant poets and their audience after I678, led to the publication of emblem books which combined the characteristics of one's own religious denominations with that of another. For the first time in the history of the Dutch Republic, Protestant poets and their audience accepted religious imagery, acknowledging the fact that the visual arts stimulate the imaginative and commemorative power of the human mind in ways texts cannot. When the religious love emblem began to flourish in the Southern Netherlands from I620, the custom of imparting religious instruction by means of images in Dutch Protestant poetry was as yet unestablished, and, it seems, unaccepted. The Protestant emblematists lived and worked in a tradition that dictated reserve with regard to imagery in the perception of faith. Considering the fact that none of them provided an apology for displaying images after I678, it can be assumed that they took advantage of a tacit and newly reached agreement on deploying images as an aid to the believer's memory and inner life-a so-called didactic aid, based on the notion that the image 'serves as a necessary but inadequate sign of the invisible'. 44

There were certainly limits to this process of appropriation: the emblematists purposely created a distance between their own work and the Roman Catholic emblems, and did not inform their readers about the origins of their visual images and emblematic concepts. The Protestant emblem books lacked any outspoken allusions in defence of appropriating Roman Catholic legacy, which might have caused these sources to be recognised; and it was not before I724 that a precursor was acknowledged, when Hugo's name was explicitly mentioned on the title page of Suderman's De Godlievende Ziel.

What is the significance of the fact that this transmission was initiated by Anabaptist poets, all of them publishing their work in Amsterdam? They were representatives of a denomination which was not dominant in the Republic at the end of the I7th century. ${ }^{45}$ Moreover, they were operating in a city and region known for its relative toleration with respect to Roman Catholics. These two factors possibly account for the fact that the process of appropriation met with little resistance. 
The reason why such possibilities arose in the Dutch Republic late in the I7th century is perhaps related to political developments. Border traffic between the Dutch Republic and surrounding countries became a more natural and less risky affair after the Peace of Munster in I648. During the first part of the I7th century, the Reformed Church-uniquely privileged in the Republic, but not officially established ${ }^{46}$ - was protected and maintained while other religions were prevented from becoming manifest in the public sphere. After I650, and particularly during the last quarter of the century, the other, tolerated religious denominations acquired more liberties. The authorities embarked on a new politics for dealing with religious differences in society. There was a concerted effort to maintain the equilibrium between the main, public church, several smaller protestant movements, and the large minority of Roman Catholics. ${ }^{47}$

However, political developments alone do not fully account for the emerging leeway for appropriation. It appears that by the end of the I 7 th century religious culture took a direction, within the Republic, which can be characterised as a shift away from attention for the church towards attention for the individual, to the effect of deconfessionalisation. Similar changes occurred elsewhere in Europe. Drawing evidence from the analyses of numerous aspects of early modern English culture which range from literature to feasts and from science to language, the British historian Sommerville concludes in his study The Secularization of Early Modern England: From Religious Culture to Religious Faith that there was a new focus on the interior life of the believer in all religious denominations. ${ }^{48}$

Before these observations were made by Sommerville, it had been established by David S. Reynolds in Faith in Fiction: The Emergence of Religious Literature in America that a growing religious toleration and diversity can find a counterpart in literary developments. ${ }^{49}$ The reduction of political and societal interests in the specificity of religious conviction brings about a certain scope for the exchange of thoughts; for example they may be recorded in literature. There is also the potential to annexe literary genres that belonged to others first or were developed elsewhere. Similar processes would then account for the introduction of the religious emblem as a genre amongst a Protestant audience. In support of this conjecture, it is noteworthy to point out that the Protestant religious emblematics, such as they were from then on created, refrained from emphatically justifying the Protestant cause. Rather, the orientation was on developing the believer's soul. Emblematic features derived from another denomination are deployed in shaping the reader's faith experience in Protestant fashion. The adaptation of concepts of other denominations to the preferences of Protestant readership did not lead to a form of polemics with the 'other'. 
The case of the religious love emblem in the Dutch Republic seems to support Kaplan's thesis that lay people played a significant role in managing and containing confessional conflicts in the early modern era, although further research into the literature of other regions with mixed religions is needed in order to establish the role of literature in the practice of religious toleration in more detail.

As for the Dutch situation: Kaplan argued that a distinction was made in the Dutch Republic between the public and private sphere, which enabled magistrates to uphold the integrity of a Protestant political order, while avoiding the social turmoil of religious violence. ${ }^{50}$ Did this distinction lead to the differences that can be noticed in the reception and production of religious literature? Previous research has revealed that within the Dutch Republic, during the whole of the I7th century, books with certain confessional overtones were owned and read by people from different denominations. ${ }^{51}$ This use of literature took place in private, while the publication of literature was a public event. Was the adaptation of Roman Catholic models by Protestant emblematists hindered by the fact that publishing interconfessional literature was a violation of (unwritten) rules in Dutch society before I680?

It seems to me that there was no case of a large-scale, more or less overt Roman Catholic influence on Protestant religious literature in the Dutch Republic during the period before I678. This is not to deny that influence at all, but it was certainly not very visible: the Roman Catholic roots of one of the best known sonnets in Dutch literature of the first half of the I7th century (Jacobus Revius's 'Hij droech onse smerten' [He bore our pains]) have only been discovered in the 2oth century. These roots were carefully hidden by Revius, who, as a minister in the Dutch Reformed church, was apparently restricted in identifying the direct (Roman Catholic) source of the line of thought in this particular sonnet. While he paid tribute to a number of Protestant authors (Du Bartas for instance) in his poetry, his Roman Catholic sources were hidden.

It is clear that literary historical research, unaware of the interconfessional nature of some of the religious literature at the time, so far has been more prominently focussed on the overt polemic between denominations-as in the case of the reformed clergymen's negative reaction to the all too emphatic Roman Catholic plays by the well-known Amsterdam poet and playwright Joost van den Vondel. ${ }^{52}$ Literary processes involving blending and reconciliation have been largely ignored; a shift of critical focus may reveal a different reality. When trying to determine what processes went on in literature, the question of the results of the confrontation and interaction between printing and writing within different confessional groups becomes pertinent.

The latitudes and limitations of confessional coexistence in and through literature are visible in the case of the introduction of religious emblems in the 
Dutch Republic: such an overt display of Roman Catholic influences was apparently unacceptable in the first half of the I7th century. Even though there were substantial areas of borrowing and overlap in the use of devotional literature, on the production side practices and precepts could not be shared between the Roman Catholic and Protestant confessions until the end of the I7th century. These developments seem to contradict the thesis of growing anti-Catholicism amongst laypeople in the Netherlands around I680.

\section{Faculty of Humanities, Department of Dutch Language and Culture, Utrecht University, Trans I0, 35 I2 JK Utrecht e.stronks@uu.nl}

\section{REFERENCES}

${ }^{1}$ Cambridge, London: Harvard University Press, 2007.

2 In the early modern era, 'toleration' was related to the original meaning of the verb 'to tolerate' (to endure). See Benjamin J. Kaplan, Divided, p. 8, and Jürgen Habermas, 'Religious Toleration-The Pacemaker for Cultural Rights', Philosophy 79 (2004) 5-I8. Editorial comments, partial translation of this present article and translation of all Dutch originals: Aleid Fokkema of Lighthouse Texts. All images are reproduced from the site of the Emblem Project Utrecht (http://emblems.let.uu.nl) (date last accessed I2 March 2009).

3 Kaplan, Divided, p. 8.

4 Ibid., pp. 38, I3 I and 243.

${ }^{5}$ Further research is due in the context of the research project coordinated by Marc Van Vaeck and Els Stronks, 'The Religious Emblem Tradition in the Low Countries in the Light of Herman Hugo's Pia Desideria.' See http://emblems.let.uu. nl/project_project_info.html\#PiaDesideria. This research profits from the results of research carried out by the Emblem Project Utrecht (EPU) (date last accessed I2 March 2009).

${ }^{6}$ See Literature and Theology 22, I (2008) $32-47$.

7 Traditionally, Hugo's Pia Desideria is placed within the subgenre of the love emblem. See Gabrielle D. Rödter, Via piae animae. Grundlagenuntersuchung zur emblematischen Verknüpfung von Bild und Wort in den 'Pia desideria' (I624) des Herman Hugo S.J. (I 588-I629), (Frankfurt a/M: Lang, I992), p. 2I; and G. Richard Dimler, 'Herman Hugo's Pia Desideria' in Karel A.E. Enenkel and Arnoud Q. Visser (eds) Mundus Emblematicus: Studies in Neo-Latin Emblem Books (Turnhout: Brepols, 2003), p. 354.

8 Virkar-Yates, 'The Heart's Bower: Emblematics in Gerard Manley Hopkins's The Wreck of the Deutschland (I876)', Literature and Theology 22 (2008) 34.

9 See E.M.F. Verheggen, Beelden voor passie en hartstocht: bid- en devotieprenten in de Noordelijke Nederlandsen, $17^{\text {de }}$ en $18^{\text {de }}$ eeuw (Zutphen: Walburg Pers, 2006).

10 See Ernestine van der Wall, 'Petrus Serrarius (I600-I669) et l'interprétation de l'Écriture', Cahiers Spinoza 5 (I984-I985) I87-2I7.

11 See http://emblems.let.uu.nl/hui624 o2o.html; http://emblem.libraries.psu. edu/qu202_or.htm; and http://emblems. let.uu.nl/lui685030.html for more information on these pictures. I have purposely selected a pictura of Luyken that is not closely related to Hugo's original. Some picturae in Jezus en de Ziel show fewer alterations (see for instance Luyken's 
emblem I2, at http://emblems.let.uu.nl/ lui6850I2.html), but the majority of picturae were profoundly transformed (date last accessed I2 March 2009).

12 Several reprints of Jezus en de Ziel were published shortly after I678. The related emblem book Goddelyke Liefde-vlammen [Divine love flames] by Johannes Boekholt was published in I69I, followed by a remake of Vaenius's Amoris Divini Emblemata (titled: Zinnebeelden der Goddelyke Liefde) by Theodorus Danckerts in Amsterdam in I703. Jan van Hoogstraten followed suit with the publication of his Zegepraal der Goddelijke Liefde [The triumph of divine love] in I709. In I7II, another remake of Vaenius's Amoris Divini Emblemata was published by Johan van Oosterwyck (titled Othonis Vaenii Emblemata Amoris Divini, of Heilige Zinnebeelden der Goddelyke Liefde). In I724, Jan Suderman published his De Godlievende Ziel [The God-loving soul] and shortly after that, in I726, Claas Bruin published Aanmerkingen op Otto van Veens Zinnebeelden der Goddelijke Liefde [remarks on Otto van Veen's images of Divine Love]. Almost all of these emblem books were reprinted several times; even Serrarius's emblems were republished in I7I3. This overview is based on John Landwehr, Emblem and Fable Books Printed in the Low Countries 1542-1813: A Bibliography (Utrecht: Hes, I988) on the Dutch central Picarta catalogue, and on Karel Porteman, Inleiding tot de Nederlandse emblemataliteratuur (Groningen: Wolters-Noordhoff, 1977).

13 John Marshall, John Locke, Toleration and Early Enlightenment Culture: Religious Intoleration and Arguments for Religious Toleration in Early Modern and 'Early Enlightenment' Europe (Cambridge: Cambridge U.P, 2006), pp. 3, I64, I72-4.

14 Maarten Prak, 'The Politics of Intoleration: Citizenship and Religion in the Dutch Republic' in R. Po-Chai Hasia and Henk van Nierop (eds) Calvinism and Toleration in the Dutch Golden Age (Cambridge: Cambridge U.P, 2002), pp. $159-75$.
15 Jonathan Israel, Enlightenment Contested. Philosophy, Modernity, and the Emancipation of Man, 1670-1753 (New York, etc.: Oxford U.P, 2006), pp. 3I, 380-I.

${ }^{16}$ See Christine Kooi, " "A Serpent in the Bosom of Our Dear Fatherland:" Reformed Reaction to the Holland Mission in the Seventeenth Century' in Arie J. Gelderblom, Jan L. de Jong and Marc Van Vaeck (eds) The Low Countries as Crossroads of Religious Beliefs: Intersections. Yearbook for Early Modern Studies 3 (2003), (Leiden: Brill, 2004), pp. I65-76.

17 Roger Chartier, 'Genre between Literature and History', Modern Language Quarterly 67 (2006) I 36. Julie Saunders recently presented a glossary of terminology used in this approach in her Adaptation and Appropriation (London and New York: Routledge, 2006), pp. I6I-4. For the purpose of this article, this glossary is used as reference.

${ }^{18}$ Roger Chartier, Forms and Meanings: Texts, Performances, and Audiences from Codex to Computer (Philadelphia: Philadelphia U.P., I995), pp. 2-3, 49-50.

19 See M.A. Schenkeveld-van der Dussen, Dutch Literature in the Age of Rembrandt: Themes and Ideas (Amsterdam: Benjamins, I99I), p. 66 and Arie J. Gelderblom, 'Who were Jan Luyken's readers?' in Ralph Dekoninck and Agnès Guiderdoni-Bruslé (eds) Emblemata sacra: rhétorique et herméneutique du discours sacré dans la littérature en images $=$ the rhetoric and hermeneutics of illustrated sacred discourse (Turnhout: Brepols, 2007), pp. 499-508.

${ }^{20}$ See for instance J. B. H. Alblas, Johannes Boekholt (1656-1693): The First Dutch Publisher of John Bunyan and other English Authors; With a Descriptive Bibliography of His Publications (Nieuwkoop: De Graaf, I987), p. I05.

21 Initially, only male role models were portrayed. This changed when the genre evolved.

22 Religion also played a role in the I6thand early I7th-century tradition of humanist emblem books in Latin deriving from Alciato's example, but in an a-confessional 
mode, as was recently argued by Arnoud Visser. See Arnoud S. Q. Visser, 'Escaping the Reformation in the Republic of Letters: Confessional Silence in Latin Emblem Books', Church History and Religious Culture 88 (2008) I 39-67.

23 See Els Stronks, 'The Emblem and the Low Countries', in Peter M. Daly (ed) A Companion to Emblem Studies (New York: AMP Press, 2008).

${ }^{24}$ Karel Porteman, 'From First Sight to Insight. The Emblem in the Low Countries' in The Low Countries. Arts and Society in Flanders and the Netherlands. A Yearbook (Rekkem: Stichting Ons Erfdeel, I993).

25 See Gelderblom, Investing, p. I38.

${ }^{26}$ See for the original texts: http://emblems. let.uu.nl/heI6I3008.html (date last accessed I 2 March 2009).

27 See Gelderblom, Investing, p. I35.

28 Arnoud S. Q. Visser, 'Commonplaces of Catholic Love' in Learned Love (The Hague: Edita, 2007), pp. 33-48.

29 As recently concluded by Karel Porteman, 'Boete Adamsz. van Bolswert's Duyfkens ende Willemynkens Pelgrimagie (I627): From the religious love emblem towards a devotional strip for girls' in Paul Catteeuw, M. Jabobs, S. Rieuwerts, et al. (eds) Toplore: Stories and Songs (Trier: Wissenschaftlicher Verlag, 2006), p. I62.

30 See Johan Verberckmoes, 'Comic traditions in Adrianus Poirters' Het masker van de wereldt afgetrocken' in The Jesuits and the Emblem Tradition, Imago Figurata. Studies, Vol. Ia (Turnhout: Brepols, I999), pp. $34 \mathrm{I}-52$.

31 See Marianne Shapiro and Michael Shapiro, 'Dialogism and the Addressee in Lyric Poetry', University of Toronto Quarterly 6I, 3 (I992) 394.

32 The Latin original can be found at: http://emblems.let.uu.nl/hui624020.html. Trans. by G. Huijing (date last accessed I2 March 2009).

${ }^{33}$ See Patrick S. Diehl, The Medieval European Religious Lyric: An Ars Poetica (Berkeley, Los Angeles, London: University of California Press, I985), p. 68.
${ }^{34}$ Cf. Liesbeth Korthals Altes, 'Some dilemmas of an Ethics of Literature' in Gaye Williams Ortiz and Clara A.B Joseph (eds) Theology and Literature: Rethinking Reader Responsibility (Basingstoke: Palgrave McMillan, 2006), p. 27.

35 Karel Porteman, Boete Adamsz, p. I 59.

36 See Els Stronks, 'The Revival of the Dutch Love Emblem' Emblematica Is (2007) 319-42 and Anne Buschhoff, Die Liebesemblematik des Otto van Veen: Die Amorum emblemata (1608) und die Amoris divini emblemata (1615) (Bremen: Hauschild, 2004), pp. 252-3.

37 http://emblems.let.uu.nl/hu 689008 .html (date last accessed I2 March 2009).

38 http://emblems.let.uu.nl/hu I689frontoo6. html (date last accessed I2 March 2009).

39 See Francios Lebrun, 'The Two Reformations: Communal Devotions and Personal Piety' in Roger Chartier (ed) A History of Private Life: Passions of the Renaissance (Cambridge: Harvard U.P., I989), pp. 69-I09; and Marc R. Forster, 'Domestic Devotions and Family Piety in German Catholicism' in Marc R. Forster and Benjamin J. Kaplan (eds) Piety and Family in Early Modern Europe: Essays in Honor of Steven Ozment (Aldershot: Ashgate, 2005), pp. 97-II4.

${ }^{40}$ In the preface to Jezus en de Ziel Luyken wrote: '[...] whilst reading, the reader should (when it comes to the Eternal Deity) never imagine that we, with this illustration, mean anything else than a physical portrayal of Christ in his assumed form of a Servant, as he walked here on Earth, a man among men, a visible and tangible appearance for our outer Eyes and Hands to relate to [...]. For his eternal Deity may not and cannot be depicted'. See for original quote in Dutch: http:// emblems.let.uu.nl/lu I 685 frontoo2.html (date last accessed I2 March 2009).

${ }^{41}$ See for all three original quotes in Dutch: http://emblems.let.uu.nl/sui 724 frontooz.html (date last accessed I2 March 2009).

${ }^{42}$ See for instance Joke Spaans, 'Religious Policies in the Seventeenth-Century 
Dutch Republic' in Ronnie Po-chia Hsia and Henk van Nierop (eds) Calvinism and Religious Toleration in the Dutch Golden Age (Cambridge: Cambridge University Press, 2002), pp. 72-86.

43 See for the original quote in Dutch: http:// emblems.let.uu.nl/su I 724 frontoo2.html (date last accessed I2 March 2009).

44 Also see Huston Diehl, 'Graven Images: Protestants Emblem Books in England', Renaissance Quarterly 39 (1986) 60.

45 In the Dutch Republic, the effects of iconoclasm were long felt amongst poets (and artists) of all Protestants denominations, but were especially restrictive for the Calvinists. I intend to shed more light on the relation between Dutch opinions about the inappropriateness of religious imagery and the development of the religious emblem in the Dutch Republic in my next article, using Mia Mochizuki's The Netherlandish Image after Iconoclasm, 1566-1672. Material Religion in the Dutch Golden Age (Aldershot: Ashgate, 2008) as the starting point of my research.

46 See Kaplan, 'Dutch Particularism and the Calvinist Quest for "Holy Uniformity", Archiv fur Reformationsgeschichte: Internationale Zeitschrift zur Erforschung der Reformation 82 (I99I) 239-56.

47 See Charles Parker, Faith on the Margins: Catholics and Catholicism in the Dutch Golden
Age (Cambridge: Harvard University Press, 2008); Joke Spaans, 'Violent Dreams, Peaceful Coexistence: On the Absence of Religious Violence in the Dutch Republic', De zeventiende eeuw I 8 (2003) I49-66; Judith Pollmann, 'From Freedom of Conscience to Confessional Segregation? Religious Choice and Toleration in the Dutch Republic, I580-I750' in Richard Bonney and David Trim (eds) Persecution and Pluralism: Calvinists and Religious Minorities in Early Modern Europe, 1550-1700, Studies in the History of Religious and Political Pluralism 2 (Oxford and Bern: Peter Lang, 2006), pp. I23-48; and Mary Heimann, 'Christianity in Western Europe from the Enlightenment' in Adrian Hastings (ed) A World History of Christianity (Grand Rapids and Cambridge: William Eerdmans Publishing Company, I999), pp. 459-60.

48 See C. John Sommerville, The Secularization of Early Modern England: From Religious Culture to Religious Faith (Oxford: Oxford U. P., I992), pp. I65-6.

49 David S. Reynolds, Faith in Fiction (Cambridge: Harvard U.P., I98I), p. 2.

50 Kaplan, Divided, pp. 262-3.

51 Frijhoff and Spies, p. 257.

52 Schenkeveld-van der Dussen, Dutch, pp. 50-7I. 